\title{
Impact of production season on the chemical composition and health properties of goat milk and rennet cheese
}

\author{
Stanisław Milewski ${ }^{1}$, Katarzyna Ząbek ${ }^{1 *}$, Zofia Antoszkiewicz², Zenon Tański ${ }^{1}$, Alicja Sobczak ${ }^{1}$ \\ ${ }^{1}$ University of Warmia and Mazury in Olsztyn Faculty of Animal Bioengineering, Department of Sheep and Goat Breeding, Oczapowskiego 5, \\ 10-957, Olsztyn, Poland, ${ }^{2}$ University of Warmia and Mazury in Olsztyn Faculty of Animal Bioengineering, Department of Animal Nutrition and \\ Feed Science, Oczapowskiego 5, 10-957, Olsztyn, Poland
}

\section{A B S T R A C T}

This study compared selected parameters of milk and rennet cheese produced from milk obtained from alpine goats during winter and summer feeding under climatic conditions of the Warmia and Mazury region. Milk from the winter season contained more protein, less vitamin $A$ and over seven times less vitamin $E$ than milk obtained in summer. In cheese from the winter season, the content of dry matter, fat, protein and vitamin A was lower when compared with cheese from the summer period. The content of total biogenic amines in cheese was almost twice as high in winter than in summer (1056.4 vs $567.6 \mathrm{mg} / \mathrm{kg})$. Winter cheese contained more cadaverines and histamine than summer cheese. The content of tyramine and putrescine was comparable in cheese from both seasons and was higher than the level of histamine. Milk fat from milk obtained in winter contained more long-chained SFA and MUFA in comparison with the summer period. Fat from cheese produced in summer had a higher content of SFA, CLA and ALA, whereas cheese from the period of winter feeding contained more $\mathrm{C}_{16: 0}$ izo and $\mathrm{C}_{18: 1}$. The content of hyper- and hypocholesterolemnic acids was comparable in milk and in cheese with a slightly smaller proportion of hyper-acids and a slightly higher proportion of hypocholesterolemnic acids during summer feeding of goats. In conclusion, it was found that the feeding season had a minor impact on the chemical composition of milk, although it significantly differentiated the chemical composition of rennet cheese produced from that milk and the health quality parameters of both products. Milk from winter feeding had a higher content of protein, whereas the chemical composition of cheese was more beneficial in winter as the content of dry matter, fat and protein was higher. The health properties of both products were more beneficial in summer, which was determined by the profile of fatty acids and the content of vitamin A.

Keywords: Alpine goats; Cheese; Milk; Seasonal changes

\section{INTRODUCTION}

Goat milk is a valuable food product and a raw material used to produce products of high quality and flavour properties (Chen et al., 2016). Although it has been included in the human diet since goats were domesticated, the importance of goat milk has been increasing along with its popularization as a rich source of nutrients and functional components (Nurliyani et al., 2015)). In the content of dry matter, fat, protein and lactose, goat milk is comparable to cow's milk, although there are substantial differences in the structure of protein and fat (Strzałkowska et al., 2012). In terms of protein, these differences involve a smaller diameter of casein micelles and a lower content of $\alpha_{\mathrm{s} 1}$ case in fraction. Fat, apart from a smaller diameter of micelles (Chen et al., 2016; Slačanac et al., 2012), has a higher concentration of short-chained and medium-chained fatty acids. They determine the higher digestibility and absorption of both these nutrients and have a significant impact on the health properties of milk. The chemical composition of goat milk and parameters of health quality, such as concentration of fat and the profile of its acids, content of lipid-soluble vitamins A and $\mathrm{E}$ and level of cholesterol are determined, to a large degree, by nutritional factors. This has been confirmed by the results of studies that indicate substantial differences in the basic composition of milk obtained during summer and winter feeding (Bernacka, 2005) or autumn-winter feeding (Wolanciuk et al., 2013). Talpur et al. (2008) demonstrated considerable changes that occur throughout the year in the

\footnotetext{
*Corresponding author:

Katarzyna Ząbek, University of Warmia and Mazury in Olsztyn Faculty of Animal Bioengineering, Department of Sheep and Goat Breeding,

Oczapowskiego 5, 10-957, Olsztyn, Poland. Phone: +48895233806, Fax:+48895245105. E-mail: katarzyna.zabek@uwm.edu.pl

Received: 31 March 2017; $\quad$ Accepted: 07 January 2018
} 
composition of fatty acids in milk obtained from goats on a traditional feeding regimen. A seasonally diversified composition of the ration, the phase of lactation, collecting and manufacturing conditions determine the production and content of biogenic amines in milk and cheese. The concentration of these compounds in fresh milk is low (approximately $1 \mathrm{mg} / \mathrm{dm}^{3}$ ) although in maturing cheese it may reach over 2,500 mg/kg (Karovičowá and Kohajdová, 2005; Wiśniewska and Reps, 2007). Biogenic amines are the components that are responsible for quality, flavour and aroma of fermented products, including cheese. Their presence results mainly from the activity of lactic acid bacteria and enteric bacteria which produce enzymes capable of decarboxylating specific amine precursors in fermented products (Hernández-Orte et al., 2008). Therefore, a change in the amino acid composition and content of proteins is an important side-effect of increasing the content of biogenic amines; furthermore, an excess of amines in feed and food may be toxic (Shalaby, 1996; Fusi et al., 2004). There are two reasons for determining the content of biogenic amines: their potential toxicity and the possibility to use them as quality markers (Dadákova et al., 2009).

As a result of seasonal changes in milk quality, it is expected to see differences in the quality of cheese produced from such raw material. The research hypothesis assumes that milk and cheese from summer feeding will differ in their basic composition (most of all, the profile of fatty acids and the concentration of cholesterol and lipid-soluble vitamins in fat as well as biogenic amines will be different) in comparison with the products from winter feeding.

The aim of the study was to evaluate the chemical composition and content of selected biologically active compounds that determine health quality of milk and cheese by perform a comparative analysis of goat milk and rennet cheese with a short maturation period obtained and produced during winter and summer feeding under climatic conditions in the Warmia and Mazury region.

\section{MATERIAL AND METHODS}

The analysis included feed, milk and short-maturing rennet cheese produced from that milk. Milk and cheese originated from the "Nad Arem" farm located in Kierźliny near Barczewo (Warmia and Mazury region). It is a region located in north-east Poland, with access to the Baltic sea. The farm has a long-standing tradition and an established position in the region. It is included in the "Dziedzictwo Kulinarne Warmia Mazury Powiśle" ("Culinary Heritage Warmia Mazury Powiśle") network that operates according to the criteria specified by the network "Sieć Regionalna
Dziedzictwa Regionalnego Europa” ("Regional Network of Culinary Heritage Europe”).

In the goat byre 180 alpine goats are reared. Female goats were aged 3-5 years. Animals are reared in a hall building on deep litter. Goats were milked twice a day with a portable milking unit. The obtained milk was processed on site with final products such as rennet cheese. In winter feeding, grass haylage was fed ad libitum and was supplemented with wheat bran $(0.1 \mathrm{~kg} / \mathrm{head} /$ day $)$ and oat grain $(0.3 \mathrm{~kg} /$ head/day). Silage was fed twice a day at $7 \mathrm{am}$ and $16 \mathrm{pm}$. Bran and oats were fed during milking time. Summer feeding was based on grass forage supplemented with oat grain $(0.3 \mathrm{~kg} / \mathrm{head} /$ day $)$ during milking time. The animals graze in a pasture all day. They were herded only into the morning milking. In both seasons, feed samples were collected three times: at the beginning, in the middle, and at the end of a given season according to PN-EN ISO 6497. Samples of grass forage with min. $0.5 \mathrm{~kg}$ were collected manually at 5 points of pasture, with plants covered by a square frame with a sides of 1 meter. These samples were mixed with each other to give an aggregate sample of $4 \mathrm{~kg}$ which was used to further analysis. Silage samples were collected from 5 bales. The primary samples were taken by sonde with a $300 \mathrm{~mm}$ long $5 \mathrm{~mm}$, diameter and volume of $680 \mathrm{~cm}^{3}$. Wheat bran and oat grain samples from 5 bags were collected with a closed sampler at $850 \mathrm{~mm}$ length and $25 \mathrm{~mm}$ diameter with 3 chambers. All feed samples were packed tightly in bags and transported under refrigerated conditions to the laboratory. The evaluation of milk and cheese was performed for 10 months: during 5 months of winter feeding from December till April and for 5 months of summer feeding from May till September. The samples were collected from a bulk tank milk of the whole herd (morning and evening milking) between the $10^{\text {th }}$ and $15^{\text {th }}$ day of each month. The samples of cheese were taken randomly from the produced batches after a 30 days maturation period and straight before cheese batches were sent for retail selling. The collected samples were analysed in three repetitions.

The basic chemical composition was determined in the samples of feed with standard methods (AOAC, 2005). The content of dry matter was measured with a dryer method at $105{ }^{\circ} \mathrm{C}$, crude ash - by combusting in a muffle furnace at $600{ }^{\circ} \mathrm{C}$, total protein with Kjeldahl's method on a FOSS 2200 apparatus (Kjeltec, Foss Tecator), ether extract - with Soxhlet's method on a FOSS SOXTEC SYSTEM 2043 apparatus, and crude fiber - on a FIBERTEC System M 2100 apparatus (Hot Extractor, Foss Tecator). The nutritional value of feed was presented in INRA units (Table 1). In addition, the samples were tested for the content of b-carotene according to Manz (1986) (separation of ether extracts of the samples on the columns with 


\begin{tabular}{|c|c|c|c|c|}
\hline \multirow[t]{2}{*}{ Specification } & Haylage & Oat & Wheat bran & Pasture \\
\hline & $\mathrm{n}=9$ & $\mathrm{n}=9$ & $\mathrm{n}=9$ & $\mathrm{n}=9$ \\
\hline Dry matter & 421.6 & 852.2 & 855.5 & 314.9 \\
\hline Crude ash & 97.5 & 30.6 & 61.5 & 89.0 \\
\hline Crude protein & 123.7 & 115.5 & 196.0 & 143.7 \\
\hline Crude fat & 28.4 & 39.1 & 30.6 & 22.8 \\
\hline Crude fiber & 258.5 & 139.2 & 122.2 & 290.8 \\
\hline$\beta$-Carotene & 294 & 0.3 & 0.20 & 527 \\
\hline Vitamin E & 19.1 & 10.8 & 12.3 & 44.0 \\
\hline UFL & 0.72 & 1.01 & 0.91 & 0.87 \\
\hline PDIN & 71.79 & 77.04 & 129.8 & 66.99 \\
\hline PDIE & 75.29 & 87.5 & 102.62 & 80.93 \\
\hline$C_{10: 0}$ & - & 0.03 & 0.02 & - \\
\hline$C_{12: 0}$ & 0.95 & 0.06 & 0.07 & 0.63 \\
\hline$C_{12: 1}$ & 0.47 & - & - & - \\
\hline$C_{14: 0}$ & 1.09 & 0.38 & 0.14 & 1.25 \\
\hline$C_{14: 1}$ & 0.57 & 0.08 & 0.00 & - \\
\hline$C_{15: 0}$ & 1.09 & 0.15 & 0.13 & 0.77 \\
\hline$C_{16: 0}$ & 23.76 & 29.78 & 17.25 & 17.90 \\
\hline$C_{16: 1}$ & 1.90 & 0.32 & 0.19 & 0.88 \\
\hline$C_{17: 0}$ & 0.72 & 0.70 & 0.12 & 0.49 \\
\hline$C_{17: 1}$ & 0.70 & 0.05 & 0.08 & 0.26 \\
\hline$C_{18: 0}$ & 4.67 & 3.08 & 1.17 & 3.76 \\
\hline$C_{18: 1}$ & 14.82 & 51.08 & 17.05 & 8.45 \\
\hline$C_{18: 2} n-6$ & 31.22 & 12.71 & 57.75 & 24.01 \\
\hline$C_{18: 3} n-3$ & 16.91 & 0.11 & 4.83 & 39.84 \\
\hline$C_{20: 0}$ & 1.13 & 0.32 & 0.18 & 1.45 \\
\hline$C_{20: 1}$ & - & 1.04 & 0.79 & - \\
\hline$C_{20: 2} n-6$ & - & - & 0.11 & - \\
\hline$C_{20: 4} n-6$ & - & 0.11 & 0.12 & - \\
\hline
\end{tabular}

UFL - feed unit for milk production; PDIN - protein digested in the intestine subject to available nitrogen; PDIE - protein digested in the intestine subject to available energy

aluminum oxide; eluents: petroleum ether and anhydrous ethyl alcohol; extract absorbance measurement at $450 \mathrm{~nm}$ wavelength, EPOLL-20, b-Carotene Type I standard, synthetic, Sigma-Aldrich) and the content of vitamin E according to PN-EN-ISO 6867:2002; (separation of ethanol and hexane extracts of the samples; HPLC method in the reversed phase system, Nukleosil $C_{18}$ column, $E_{x} 293$ and $\mathrm{E}_{\mathrm{m}} 326$ fluorescent detector, a mobile methanol: water phase (v: v, 95:5), external standards: (士)-b-tocopherol DL-all-rac b-tocopherol, Sigma-Aldrich).

The content of dry matter, fat, protein and lactose was determined in the samples of milk with an instrumental method on a MilcoScan. The chemical composition of cheese samples was measured with standard methods (AOAC, 2005): dry matter - with a dryer method at $105^{\circ} \mathrm{C}$; crude ash - by combusting in a muffle furnace at $600{ }^{\circ} \mathrm{C}$; total protein - with Kiejdahl's method; and crude fat - with Soxhlet's method.
Methyl derivatives were obtained from fat contained in feed (Soxhlet's method), milk (Roese-Gottlieb's method) and cheese (Schmid-Bądzyński-Ratzlaff's method) and the profile of fatty acids was determined with a gas chromatography (GC) method. A VARIAN CP-3800 chromatograph was used with a flame-ion detector (FID) and a $50 \mathrm{~m}$ capillary column with an internal diameter of $0.25 \mathrm{~mm}$. The temperature of the detector was $250^{\circ} \mathrm{C}$, in the injector: $225^{\circ} \mathrm{C}$, and of the column: $50{ }^{\circ} \mathrm{C} \rightarrow 200^{\circ} \mathrm{C}$; helium was the carrier gas (flow at $1.2 \mathrm{ml} / \mathrm{min}$ ).

The values of indices: thrombogenic (IT) and atherogenic (IA) were calculated for milk and cheese fat according to the formulas proposed by Ulbricht and Southgate (1991):

$$
\begin{aligned}
\mathrm{IA}= & \left(\mathrm{C}_{12: 0}+4 \mathrm{C}_{14: 0}+\mathrm{C}_{16: 0}\right) /(\text { PUFA } \mathrm{n}-3+\text { PUFA } \mathrm{n}-6+ \\
& \text { MUFA }) \\
\mathrm{IT}= & \left(\mathrm{C}_{14: 0}+\mathrm{C}_{16: 0}+\mathrm{C}_{18: 0}\right) /(0,5 \text { MUFA }+0,5 \text { PUFA n-6 }+ \\
& \text { 3PUFA n-3 }+ \text { PUFA n-3/PUFA n- }) .
\end{aligned}
$$

In milk and cheese extracts obtained with Folch's method by Rhee et al. (1982), the content of cholesterol was determined in enzymatic reactions with cholesterol esterase and oxidase and with the use of Pointe Scientific tests. The content of vitamin A (retinol) and E ( $\alpha$-tocopherol) was determined according to Hewavitharan et al. (1996). Homogenized and weighed samples of milk and cheese $(10 \mathrm{~g}$ each) were de-proteinized with ammonia $(2 \mathrm{ml})$ and $96 \%$ ethanol $(10 \mathrm{ml})$, saponified with $50 \% \mathrm{KOH}$ in ethanol $(\mathrm{w} / \mathrm{v})(10 \mathrm{ml})$ in a water bath $\left(90^{\circ} \mathrm{C}, 15^{\prime}\right.$, under a reflux condenser); cooled samples were subsequently extracted with $2 \times 2 \mathrm{ml}$ of ethyl ether, $2 \times 20 \mathrm{ml}$ of $\mathrm{n}$-hexane; extracts washed with distilled water were evaporated until dry and dissolved in $1 \mathrm{ml}$ of $96 \%$ ethanol, filtered through a syringe filter (Supelco, $20 \mathrm{~mm}$ ) and analysed with HPLC (SHIMADZU): a Nucleosil $\mathrm{C}_{18}$ 250x4 mm) column (250x4 mm), a reverse-phase system (RP), methanol and water extract as a carrier phase (v/v 95:5); retinol measurement - a UV-VIS (336 nm) detector, $\alpha$-tocopherol measurement - a FL (Ex 293 nm, Em 326 nm) fluorescent detector. External standards: $( \pm)-\alpha$-tocopherol (DL-allrac $\alpha$-tocopherol), and Retinol, synthetic (Sigma-Aldrich). The content of biogenic amines in the cheese samples was determined with the HPLC method (SHIMADZU) with post-column derivatization with ninhydrin (Joosten and Olieman, 1986). The samples of cheese $(5 \mathrm{~g})$ were homogenized (ULTRA TURRAX, Janke \& Kunkel IKA - Labortechnik) in a $0.07 \mathrm{M}$ trisodium citrate solution, de-proteinized with $0.6 \mathrm{M}$ and $0.3 \mathrm{M}$ TCA solution, and centrifuged $\left(10,000 \mathrm{~g} 10^{\prime}, 4^{\circ} \mathrm{C}\right)$. Supernatant was filled to $10 \mathrm{ml}$ with water, filtered (a $0.22 \mu \mathrm{m}$ syringe filter (PTFE 30SF-02 CHROMACOL LTD) and placed onto a Nucleosil $\mathrm{C}_{18}$ column. In the carrier phase, an aqueous solution 
based on DMSO with sodium acetate and acidic acid was used. Ninhydrin was dissolved in the carrier phase. Colour derivatives were produced as a result of ninhydrin and high temperature (an oil bath $145^{\circ} \mathrm{C}$ ), a coil reactor $(10 \mathrm{~m}$ of Teflon tube, $\varnothing 0.25 \mathrm{~mm})$. The content of tyramine, histamine, putrescine, and cadaverine was determined with an UV-VIS detector at $546 \mathrm{~nm}$ wavelength with an external standard method (biogenic amines standards, SIGMA).

The results were statistically processed in a one-factor arrangement for the winter and summer period. The significance of differences between the periods was verified with t-Student's test. Statistica 9.0 (StatSoft Inc.) software was used for the calculations.

\section{RESULTS AND DISCUSSION}

The content of nutrients in feed (Table 1) used for winter and summer feeding of goats did not diverge from the values presented by INRA (1993). Wheat bran had a higher content of intestine-digestible proteins that originated from nitrogen and energy transformations in comparison with the other feed types, which is reflected in the data by INRA (1993) and by Calderón et al. (2007). The composition of fatty acids in feed fat during winter and summer feeding (Table 1) did not diverge from the data reported by Huuskonen et al. (2010). Fat in grass haylage and forage did not contain arachidonic acid, although it had a higher content of $\alpha$-linolenic acid compared to oat grain and wheat bran, which was consistent with the data reported by the above-mentioned authors.

Milk and cheese produced from that milk significantly differed in chemical composition and vitamin content; cheese differed additionally in the concentration of biogenic amines depending on the season of feeding (Table 2). The basic chemical composition of goat milk (Table 2) did not diverge from the data reported by Jandal (1996), Pandya and Ghodke (2007) (protein: 2.90-3.52\%; fat: $3.80-4.25 \%$; lactose: $4.08-4.27 \%$ ). Milk from winter feeding contained more protein by $17 \%(p<0.05)$ and more crude fat, which was not statistically confirmed (Table 2). Kondyli et al. (2007) also reported a higher content of protein (by $5 \%$ ) and fat (by 7\%) in winter goat milk. Milk obtained in winter contained 30\% less vitamin A $(p<0.05)$ and over seven times less vitamin $\mathrm{E}(p<0.01)$ in comparison with milk from the summer period (Table 2). Kondyli et al. (2007) also reported that winter milk had a lower content of vitamin A (by 14\%), yet more vitamin E (by $7 \%$ ) than in summer milk. The impact of season on the basic composition of milk was observed in studies by Bernacka (2005) on Polish White Improved, which was justified by a diversified content of nutrients in feeds that were fed in winter and summer. Pandya and Ghodke (2007) reported a lower concentration of vitamin A $(0.52 \mu \mathrm{g} / \mathrm{g})$ in goat milk than the level recorded in this study.

The above-mentioned authors and Debier et al. (2005) emphasized the impact of lactation period on the composition and content of lipophilic vitamins in goat milk. Cheese from the winter feeding period had a lower content of dry matter by approximately 13\% $(p<0.01)$ and of protein and fat by approximately $8 \%$ and $18 \%$, respectively, $(p<0.01)$ as well as almost two times lower concentration of vitamin $\mathrm{A}(\phi<0.05)$ in comparison with cheese produced during summer feeding (Table 2). A higher content of vitamin $\mathrm{E}$ in cheese in winter than in summer (10.11 vs. $8.22 \mu \mathrm{g} / \mathrm{g}$ of fat) was not statistically confirmed (Table 2). Haylage fed during winter with a lower content of $\beta$-carotene (provitamin of vitamin A) and $\alpha$-tocopherol (vitamin $\mathrm{E}$ ) than grass forage was supplemented with oat grain and wheat bran providing vitamin $\mathrm{E}$ during winter feeding (Table 1). Cereal grain and good quality bran when stored under optimal conditions are an effective and stable source of vitamin E. The composition of feeds that was fed in summer contained less crude fat than during winter feeding and tocopherols are ingested with lipids in feed. Graulet et al. (2011) emphasized the impact of a ration on the diversification of vitamin content in cheese.

The content of total biogenic amines in cheese from the period of winter feeding was almost twice as high as in summer (1056.4 vs. $567.6 \mathrm{mg} / \mathrm{kg}$ ) (Table 2). Among biogenic amines, the content of cadaverine was the highest in winter cheese whereas that of putrescine was the highest in cheese from the period of summer feeding. Cheese produced in winter had a higher concentration of cadaverine $(p<0.01)$ (a derivative being a product of lysine decarboxylation) and histamine $(p<0.05)$ (a derivative of histidine) than cheese produced in summer. The content of tyramine (a derivative of tyrosine) and putrescine (a derivative of ornithine) was comparable in cheese produced in winter and summer and higher than that of histamine (Table 2). According to Galgano et al. (2001), Roig-Sagues et al. (2002) and Spizzirri et al. (2013), the content of histamine in goat cheese was $20-130 \mathrm{mg} / \mathrm{kg}$ and ranged from 0 to $49 \mathrm{mg} / \mathrm{kg}$ in sheep cheese. Due to the toxic effect of histamine, its content should not exceed $50-100 \mathrm{mg} / \mathrm{kg}$ (Wiśniewska and Reps, 2007). The period of maturation is an important factor that determines the content of tyramine in goat cheese. Galgano et al. (2001) and Pinho et al. (2001) reported that the concentration of tyramine of $60 \mathrm{mg} / \mathrm{kg}$ after 15 days of maturation increased to $280 \mathrm{mg} / \mathrm{kg}$ after 60 days of maturation of goat cheese. The content of this amine in cheese tested in personal studies was comparable to the value reported by the above-mentioned authors. The preparation of raw material with different technologies 
Table 2: Chemical composition (\%), content of vitamins: A, E ( $\mu \mathrm{g} / \mathrm{g}$ of fat), cholesterol (mg/ $100 \mathrm{~g}$ of $\mathrm{milk},{ }^{*} \mathrm{mg} / 100 \mathrm{~g}$ of $\mathrm{milk}$ fat) and biogenic amines $(\mathrm{mg} / \mathrm{kg})$ in milk and cheese depending on the feeding season.

\begin{tabular}{|c|c|c|c|c|c|c|c|c|}
\hline \multirow[t]{4}{*}{ Specification } & \multicolumn{4}{|c|}{ Milk } & \multicolumn{4}{|c|}{ Cheese } \\
\hline & \multirow{2}{*}{\multicolumn{2}{|c|}{$\begin{array}{c}\text { Winter } \\
n=15\end{array}$}} & \multirow{2}{*}{\multicolumn{2}{|c|}{$\begin{array}{c}\text { Summer } \\
n=15\end{array}$}} & \multirow{2}{*}{\multicolumn{2}{|c|}{$\begin{array}{c}\text { Winter } \\
n=15\end{array}$}} & \multirow{2}{*}{\multicolumn{2}{|c|}{$\begin{array}{c}\text { Summer } \\
n=15\end{array}$}} \\
\hline & & & & & & & & \\
\hline & $\bar{X}$ & SD & $\bar{X}$ & SD & $\mathrm{X}$ & SD & $\mathrm{X}$ & SD \\
\hline Dry matter & 12.80 & 1.19 & 11.37 & 0.81 & $48.05^{Y}$ & 3.39 & $55.15^{x}$ & 1.05 \\
\hline Crude ash & - & - & - & - & 4.36 & 0.67 & 3.85 & 0.21 \\
\hline Crude protein & $3.71^{\mathrm{a}}$ & 0.49 & $3.07^{b}$ & 0.30 & $19.82^{Y}$ & 0.52 & $21.45^{x}$ & 0.79 \\
\hline Crude fat & 4.62 & 0.75 & 3.84 & 0.51 & $22.56^{Y}$ & 2.74 & $27.49^{x}$ & 0.83 \\
\hline Lactose & 4.46 & 0.05 & 4.45 & 0.05 & - & - & - & - \\
\hline Vitamin A & $18.2^{\mathrm{b}}$ & 0.15 & $26.0^{\mathrm{a}}$ & 0.04 & $4.4^{y}$ & 0.14 & $6.62^{x}$ & 0.68 \\
\hline Vitamin E & $6.71^{\mathrm{B}}$ & 0.06 & $50.8^{A}$ & 0.51 & 10.11 & 0.92 & 8.22 & 0.30 \\
\hline Cholesterol & 14.70 & 4.16 & 14.12 & 3.05 & 40.87 & 3.96 & 47.81 & 18.5 \\
\hline Cholesterol* $^{*}$ & 0.318 & - & 0.368 & - & 0.181 & - & 0.174 & - \\
\hline Tyramine & - & - & - & - & 198.5 & 36.2 & 205.3 & 81.0 \\
\hline Histamine & - & - & - & - & $101.7^{x}$ & 6.30 & $82.2^{y}$ & 11.6 \\
\hline Putrescin & - & - & - & - & 193.7 & 14.7 & 235.4 & 57.0 \\
\hline Cadaverine & - & - & - & - & $562.5^{x}$ & 26.7 & $44.7^{Y}$ & 3.54 \\
\hline $\begin{array}{l}\text { Total biogenic } \\
\text { amines }\end{array}$ & - & - & - & - & 1056.4 & & 567.6 & \\
\hline
\end{tabular}

$A, B, X, Y-P<0.01 ; a, b, x, y-P<0.05$

(pasteurized milk or milk treated with high pressure) did not always have an impact on a reduction or diversification of tyramine concentration (Novella-Rodriguez et al., 2003). Data collected by Loizzo et al. (2013) and Spizzirri et al. (2013) on the amount of biogenic amines in selected maturing goat cheese varieties indicated lower contents of tyramine, histamine, putrescine and cadaverine (6-32, 6-43, 18-86 and 19-196 $\mathrm{mg} / \mathrm{kg}$, respectively) than the values recorded in this studies. Moreover, these authors presented a wide range of concentration for tyramine: 2-2000 $\mathrm{mg} / \mathrm{kg}$, histamine: $1-1051 \mathrm{mg} / \mathrm{kg}$, putrescine: $0-523 \mathrm{mg} / \mathrm{kg}$ and cadaverine: $0.7-2101 \mathrm{mg} / \mathrm{kg}$ in cheese. Numerous factors, such as the content of free amino acids, dry matter, $\mathrm{pH}$ value and, most of all, microorganisms (Enterococcus) favours decarboxylation of amino acids and accumulation of biogenic amines (Galgano et al., 2001). No statistically proven differences in the content of cholesterol in milk obtained in winter or summer and in cheese from both seasons were observed (Table 2). The content of cholesterol in $100 \mathrm{~g}$ of milk was three times lower than in $100 \mathrm{~g}$ of cheese (14.41 vs. $44.34 \mathrm{~g} / 100 \mathrm{~g})$ although $100 \mathrm{~g}$ of crude milk fat delivered two times more cholesterol than $100 \mathrm{~g}$ of crude cheese fat $(0.343$ vs. $0.178 \mathrm{~g} / 100 \mathrm{~g}$ of fat). The content of cholesterol in tested milk did not diverge from the results $(0.255-0.306 \mathrm{~g}$ of fat) presented by Reklewska et al. (2002). In cheese produced during this studies, the concentration of cholesterol (Table 2) was lower than the values reported by Galina et al. (2007) (grazing goats: 63.2, non-grazing goats: $80.4 \mathrm{mg} / 100 \mathrm{~g}$ ) and corresponded to a lower level reported by Andrikopoulos et al. (2003) for some cheese varieties (43 mg/100 g). In milk fat from summer feeding, there were more short-chained and medium-chained SFA $\left(\mathrm{C}_{4: 0} p<0.05, \mathrm{C}_{6: 0}\right.$ $\left.p<0.01, \mathrm{C}_{8: 0} p<0.01, \mathrm{C}_{10: 0} p<0.05\right)$, long-chained PUFA, including CLA $(p<0.01), \alpha$-linolenic $\mathrm{C}_{18: 3} \mathrm{n}-3(p<0.05)$ and eicosadienoic $\left(\mathrm{C}_{20: 2}\right.$ omega- 6 , cis $\left.p<0.01\right)$ than in milk fat from the winter feeding regimen (Table 3 ).

Milk fat obtained from winter milk contained more longchained SFA compared to milk from summer feeding: $\mathrm{C}_{15: 0}\left(p<0.05, \mathrm{C}_{16: 0}\right.$ i:o $(p<0.01)$, and MUFA: $\mathrm{C}_{17: 1}$ and $\mathrm{C}_{18: 1}$ $(p<0.01)$. Fat from cheese produced in summer, similar to milk fat from this period, had a higher content of SFA and $\mathrm{C}_{6: 0}(p<0.05)$, CLA $(p<0.01), \alpha$-linolenic $\mathrm{C}_{18: 3} \mathrm{n}-3$ $(p<0.05)$, whereas cheese from winter feeding contained more $\mathrm{C}_{16: 0}$ izo and $\mathrm{C}_{18: 1}(p<0.05)$. Milk and cheese fat from the period of winter feeding had less SFA by $6 \%$ and $7 \%(p<0.05)$, respectively, and PUFA by $19 \%$ and $21 \%$ $(p<0.05)$, respectively, although more UFA by $14 \%$ and $17 \%(p<0.05)$, respectively, and MUFA by $18 \%(p<0.01)$ and $21 \%(p<0.05)$, respectively, than during summer feeding. In winter, both milk and cheese had a higher and more beneficial proportion of UFA/SFA $(p<0.05)$ whilst PUFA/MUFA ratio was lower $(p<0.01)$. Milk from the summer period had a higher proportion of PUFA $n-6$ and PUFA n-3 $(p<0.05)$ acids in fat. According to Lock and Garnsworthy (2003), the composition of fatty acids in milk from winter feeding included less CLA and more SFA than during summer feeding and there was a diversified content of $\mathrm{C}_{10: 0}, \mathrm{C}_{18: 0}, \mathrm{C}_{18: 1}$ and cis-9 $\mathrm{C}_{18: 1}$ regardless of the season. Fat from milk and cheese that were evaluated in personal studies had comparable proportions of unsaturated-tosaturated acids and PUFA to MUFA. However, during summer feeding, the proportion of UFA and MUFA in relation to SFA of milk and cheese $(p<0.05, p<0.05$, and 
Milewski, et al.

Table 3: Fatty acids profile in milk and cheese fat (\% of total fatty acid content)

\begin{tabular}{|c|c|c|c|c|c|c|c|c|}
\hline \multirow[t]{3}{*}{ Specification } & \multicolumn{4}{|c|}{ Milk } & \multicolumn{4}{|c|}{ Cheese } \\
\hline & \multicolumn{2}{|c|}{ Winter } & \multicolumn{2}{|c|}{ Summer } & \multicolumn{2}{|c|}{ Winter } & \multicolumn{2}{|c|}{ Summer } \\
\hline & $\mathrm{X}$ & SD & $X$ & SD & $\mathrm{X}$ & SD & $X$ & SD \\
\hline$C_{4: 0}$ & $1.73^{b}$ & 0.36 & $2.33^{a}$ & 0.28 & 1.98 & 0.41 & 2.35 & 0.27 \\
\hline $\mathrm{C}_{6: 0}$ & $1.97^{\mathrm{B}}$ & 0.16 & $2.57^{A}$ & 0.12 & $2.13^{y}$ & 0.39 & $2.57^{x}$ & 0.08 \\
\hline $\mathrm{C}_{8: 0}$ & $2.32^{\mathrm{B}}$ & 0.11 & $3.04^{A}$ & 0.18 & 2.52 & 0.56 & 3.36 & 0.88 \\
\hline$C_{10: 0}$ & $8.04^{b}$ & 1.04 & $9.83^{a}$ & 1.28 & 8.44 & 1.99 & 10.04 & 1.14 \\
\hline$C_{14: 1}$ & 0.24 & 0.13 & 0.13 & 0.09 & $0.42^{y}$ & 0.07 & $0.54^{x}$ & 0.06 \\
\hline$C_{15: 0}$ & $1.20^{\mathrm{a}}$ & 0.20 & $0.97^{b}$ & 0.08 & 1.16 & 0.25 & 1.02 & 0.11 \\
\hline$C_{16: 0}$ izo & $0.31^{A}$ & 0.03 & $0.23^{\mathrm{B}}$ & 0.03 & $0.32^{x}$ & 0.04 & $0.23^{y}$ & 0.05 \\
\hline$C_{17: 1}$ & $0.59^{A}$ & 0.09 & $0.34^{\mathrm{B}}$ & 0.04 & $0.56^{x}$ & 0.14 & $0.29^{Y}$ & 0.08 \\
\hline$C_{18: 1}$ & $25.51^{A}$ & 2.58 & $20.90^{B}$ & 0.97 & $25.95^{x}$ & 4.13 & $20.20^{y}$ & 1.27 \\
\hline$C_{18: 2} n-6$ (CLA) & $0.38^{\mathrm{B}}$ & 0.02 & $0.92^{A}$ & 0.12 & $0.49^{Y}$ & 0.17 & $0.97^{x}$ & 0.10 \\
\hline$C_{18: 3} n-3$ & $0.70^{\mathrm{b}}$ & 0.07 & $0.83^{a}$ & 0.08 & $0.59^{y}$ & 0.12 & $0.79^{x}$ & 0.05 \\
\hline$C_{20: 2} n-6$ & $0.00^{\mathrm{B}}$ & 0.00 & $0.03^{A}$ & 0.02 & 0.00 & 0.00 & 0.00 & 0.00 \\
\hline SFA & $69.97^{b}$ & 2.92 & $74.28^{a}$ & 1.01 & $69.69^{y}$ & 4.22 & $74.95^{x}$ & 1.25 \\
\hline MUFA & $27.25^{A}$ & 2.50 & $22.27^{\mathrm{B}}$ & 1.07 & $27.80^{x}$ & 4.23 & $21.87^{y}$ & 1.15 \\
\hline PUFA & $2.79^{b}$ & 0.47 & $3.45^{a}$ & 0.26 & $2.51^{y}$ & 0.49 & $3.19^{x}$ & 0.20 \\
\hline UFA & $30.04^{a}$ & 2.91 & $25.72^{b}$ & 1.01 & $30.31^{x}$ & 4.22 & $25.05^{y}$ & 1.25 \\
\hline MUFA/SFA & $0.39^{A}$ & 0.05 & $0.30^{\mathrm{B}}$ & 0.02 & $0.40^{x}$ & 0.08 & $0.29^{y}$ & 0.02 \\
\hline PUFA/SFA & 0.04 & 0.01 & 0.05 & 0.00 & 0.04 & 0.01 & 0.04 & 0.00 \\
\hline UFA/SFA & $0.43^{a}$ & 0.06 & $0.35^{b}$ & 0.02 & $0.44^{x}$ & 0.09 & $0.33^{y}$ & 0.02 \\
\hline PUFA/MUFA & $0.10^{B}$ & 0.01 & $0.16^{A}$ & 0.02 & $0.09^{r}$ & 0.03 & $0.15^{x}$ & 0.01 \\
\hline n-6 PUFA & $2.04^{b}$ & 0.40 & $2.54^{a}$ & 0.21 & 1.88 & 0.36 & 2.36 & 0.17 \\
\hline n-3 PUFA & $0.75^{b}$ & 0.08 & $0.91^{a}$ & 0.08 & 0.63 & 0.13 & 0.83 & 0.06 \\
\hline n-6/n-3 PUFA & 2.72 & 0.36 & 2.82 & 0.23 & 3.01 & 0.13 & 2.87 & 0.21 \\
\hline DFA $\left(U F A+C_{18: 0}\right)$ & 41.22 & 5.22 & 40.24 & 3.22 & 42.05 & 5.53 & 38.88 & 3.88 \\
\hline OFA (SFA - $\left.C_{18: 0}\right)$ & 58.79 & 5.22 & 59.76 & 3.22 & 57.95 & 5.52 & 61.12 & 3.88 \\
\hline DFA/OFA & 0.71 & 0.16 & 0.68 & 0.09 & 0.74 & 0.18 & 0.64 & 0.10 \\
\hline $\mathrm{Al}$ & 1.41 & 0.27 & 1.54 & 0.10 & 1.35 & 0.28 & 1.61 & 0.15 \\
\hline TI & 13.54 & 1.73 & 11.51 & 1.12 & 15.50 & 2.98 & 12.45 & 0.21 \\
\hline
\end{tabular}

$A, B, X, Y-P<0.01 ; a, b, x, y-P<0.05$

DFA - dietary fatty acids with a desirable (neutral or hypocholesterolemic) effect on humans

OFA - dietary fatty acids with an undesirable (hypercholesterolemic) effect on humans

$\mathrm{Al}$ - atherogenic index, $\mathrm{TI}$ - thrombogenic index

$p<0.01, p<0.05)$ and the PUFA to MUFA proportion $(p<0.01$, and $p<0.01)$ were more beneficial than in winter. Among unsaturated acids, there were more MUFA acids and less PUFA acids in milk fat and cheese fat from winter feeding and these differences were statistically confirmed (Table 3). A similar impact of season on goat milk was reported by Bernacka (2005). This author shows that CLA and PUFA concentration was higher in summer, similar to climatic conditions in Central Europe during the grazing season. In milk of goats reared in Pakistan (Talpur et al., 2008), the content of saturated acids from $\mathrm{C}_{6: 0}$ to $\mathrm{C}_{14: 0}$ and the proportion of SFA were higher in winter months and MUFA concentration was higher in summer, which differed from the results recorded in this study. As viewed by the authors, fresh forage feeding in summer favours PUFA synthesis, including conjugated acids, which probably results from a change in the pathways of fatty acid biohydrogenation in the rumen. It is believed that higher PUFA content, including PUFA $\mathrm{n}-3$, in the products from the summer period resulted from a higher concentration of $\mathrm{C}_{18: 3} \mathrm{n}-3$ which is the main acid in forage (Table 1$)$. This acid is an initial substrate for trans- 11 vaccenic acid (TVA) and conjugated cis-9, trans-11 $\mathrm{C}_{18: 2}$ linoleic acid (CLA) in a bio-hydrogenation reaction in the rumen (Lock and Garnsworthy, 2003). Both metabolites generate an increase in $\Delta$ 9-dehydrogenase activity. This enzyme catalyses transformation of vaccenic acid into endogenous CLA in the mammary gland (Lock and Garnsworthy, 2003; Lock and Barman, 2004).

The profile of fatty acids in milk and cheese produced from the above milk was comparable. Fat in both products obtained during winter feeding had a higher proportion of MUFA, which resulted in a reduction of PUFA content and PUFA/MUFA proportion. Considering health quality, it should be assumed to be less desired (Ulbricht and Southgate, 1991; Wood et al., 2003). The demonstrated changes did not, however, have any significant impact on the proportion of PUFA/SFA as well as AI and TI indices that are thought by Ulbricht and Southgate (1991) to be 
better indicators of atherogenicity and thrombogenicity than the PUFA/SFA ratio. This results from not all SFA being hypercholesterolemnic and from a protective effect also demonstrated by MUFA. The atherogenic SFA include $\mathrm{C}_{12: 0}, \mathrm{C}_{14: 0}$ and $\mathrm{C}_{16: 0}$ as they cause an increase of cholesterol and its LDL fraction in the blood plasma whereas the thrombogenic SFA include $\mathrm{C}_{14: 0}, \mathrm{C}_{16: 0}$ and $\mathrm{C}_{18: 0}$, because they stimulate the activity of platelets and their aggregation. Of polyunsaturated fatty acids, a strong anti-atherogenic activity is shown by PUFA $n-6$ by reducing blood plasma lipids whilst PUFA n-3 are anti-thrombogenic by reducing the activity of platelets. The lower thrombogenic index values recorded in the personal studies could indicate an increase in health quality of milk and cheese that were produced in summer, although the differences in relation to winter feeding regimen were not confirmed statistically. The increase in the content of vitamin A and $\mathrm{E}$ in milk from the summer period results from pasturing, as forage constitutes a good source of these vitamins (Shingfield et al., 2005; Nozière et al. 2006). Vitamin E is involved in inhibiting lipid peroxidation, including unsaturated fatty acids, especially during technological processing and storage of milk and cheese. A slightly lower proportion of vitamin $\mathrm{E}$ in cheese produced in summer than that from winter feeding could result from its consumption in processes that protect against oxidation of unsaturated fatty acids during production, maturation and storage of cheese. The results recorded during this studies suggested a higher health quality of milk obtained during summer feeding. This was associated with a higher content of vitamin A and $\mathrm{E}$ and with a more beneficial profile of fatty acids: a higher proportion of CLA and PUFA, including PUFA n-3. This was reflected in the health quality of cheese produced from such milk.

\section{REFERENCES}

Andrikopoulos, N., N. Kalogeropulos, A. Zerva, U. Zerva, M. Hassapidou and M. Kapoulas. 2003. Evaluation of cholesterol and other nutrient parameters of Greek cheese varieties. J. Food Compos. Anal. 16: 155-167.

AOAC. 2005. Association of Official Analytical Chemists. Official Methods of Analysis. $18^{\text {th }}$ ed, AOAC, Arlington.

Bernacka, H. 2005. Effect of breed and feeding season on the nutritive quality of goat milk. Folia Biol. (Kraków) 53: 99-102.

Calderón, F., B. Chauveau-Duriot, B. Martin, B. Graulet, M. Doreau and $P$. Nozière. 2007. Variation in carotenoids, vitamins $A$ and $E$, and color in cow's plasma and milk during late pregnancy and first three months of lactation. J. Dairy Sci. 90: 2335-2346.

Chen, H., C. H. Bao, G. Shu and C. H. Wang. 2016. Response surface methodology for optimizing fermentation conditions of goat yogurt with Bifidobacterium bifidum and Lactobacillus case. Emirates J. Food Agric. 28: 547-553.

Dadákova, E., M. Křižek, T. Pelikánová. 2009. Determination of biogenic amines in foods using ultra-performance liquid chromatography UPLC. Food Chem. 116: 365-370.
Debier, C., J. Pottie, C. H. Goffe and Y. Larondelle. 2005. Present knowledge and unexpected behaviours of vitamins $A$ and $E$ in colostrums and milk. Livest. Prod. Sci. 98: 135-147.

Fusi, E., L. Rossi, R. Rebucci, F. Cheli, A. Di Giancamillo, C. Domeneghini, L. Pinotti, L. Dell'Orto and A. Baldi. 2004. Administration of biogenic amines to saanen kids; Effects on growth performance meat quality and gut histology. Small Rumin. Res. 53: 1-7.

Galgano, F., G. Suzzi, F. Favati, M. Caruso, M. Martuscelli, F. Gardini and G. Salzano. 2001. Biogenic amines during ripening in 'semicotto caprino' cheese; Role of enterococci. Int. J. Food Sci. Tech. 36: 153-160.

Galina, M. A., F. Osnaya, H. M. Cuchillo and G. F. W. Haenlein. 2007. Cheese quality from milk of grazing or indoor-fed Zebu cows and Alpine crossbred goats. Small Rumin. Res. 71: 264-272.

Graulet, B., C. Chatelard, M. Lepetit, B. Blay, S. Hulin, B. Duriot and B. Martin. 2011. Carotenoids Vitamin A and E Concentrations in Saint Nectaire Cheeses According to Process and Season. 10TM International Meeting on Mountain Cheese, Dronero, Italy.

Hernández-Orte, P., A. C. Lapeňa, A. Peňa-Gallegp, J. Astrain, C. Baron, I. Pardo, L. Polo, S. Ferrer, J. Cacho and V. Ferreira. 2008. Biogenic amine determination in wine fermented in oak barrels; Factors affecting formation. Food Res. Int. 41: 697-706.

Hewavitharana, A. K., A. S. van Brakel and M. Harnett. 1996. Simultaneous liquid chromatographic determination of Vitamins $\mathrm{A} E$ and $\beta$-carotene in common dairy foods. Int. Dairy J. 6 : 613-624.

Huuskonen, A., S. Jansson, M. Honkavaara, L. Tuomisto, R. Kauppinen and E. Joki-Tokola. 2010. Meat colour fatty acid profile and carcass characteristics of hereford bulls finished on grazed pasture or grass silage-based diets with similar concentrate allowance. Livest. Prod. Sci. 131: 125-129.

INRA. 1993. In: R. Jarrige (Ed.), Institut National de la Recherche Agronomique. Alimentation des Bovins, Ovi, Caprins, Paris.

Jandal, J.M. 1996. Comparative aspects of goat and sheep milk. Small Rumin. Res. 22: 177-185.

Joosten, H.M.L.J. and C. Olieman. 1986. Determination of biogenic amines in cheese and some other food products by highperformance-liquid-chromatography in combination with thermosensitized reaction detection. J. Chromatogr. 36: 311-319.

Karovičowá, J. and Z. Kohajdová. 2005. Biogenic amines in food. Chem. Papers. 59: 70-79.

Kondyli, E., M. Katsiari. and L. P. Voutsinas. 2007. Variation of vitamin and mineral contents in raw goat milk of indigenous Greek breed during lactation. Food Chem. 100: 226-230.

Loizzo, M. R., F. Menichini, N. Picci, F. Puoci, U. G. Spizzirri and D. Restuccia. 2013. Technological aspects and analytical determination of biogenic amines in cheese. Trends Food Sci. Technol. 30: 38-55.

Lock, A. L. and P. C. Garnsworthy. 2003. Season variation in milk conjugated linoleic acid and $\Delta 9$-desaturase activity in dairy cows. Livest. Prod. Sci. 79: 47-59.

Lock, A. L. and D. E. Barman. 2004. Modifying milk fat composition of dairy cows to enhance fatty acids beneficial to human health. Lipids. 39: 1197-1206.

Manz, U. 1986. Assay Methods for Beta-carotene in ROVIMIX- $\beta-$ Carotene $10 \%$ and in Mixed Animal Feeds and of Carotene in Animal Feedstuffs Blood Plasma and Milk, Information Service, Animal Nutrition Department. $2^{\text {nd }}$ ed. Chalcombe Publications, Basel.

Novella-Rodriguez, S., M. T. Veciana-Nogués, M. Izquierdo-Pulido and M. C. Vidal-Carou. 2003. Distribution of biogenic amines 
and polyamines in Cheese. J. Food Sci. 68: 750-755.

Nozière, P., B. Graulet, A. Lucas, P. Martin, P. Grolier and M. Doreau. 2006. Carotenoids for ruminants; from forages to dairy products. Anim. Feed Sci. Tech. 131: 418-450.

Pandya, A. J. and K. M. Ghodke. 2007. Goat and sheep milk products other than cheeses and yoghurt. Small Rumin. Res. 68: 193-206.

Pinho, O., I. M. P. L. V. O. Ferreira, E. Mendes, B. M. Olivera and M. Ferreira. 2001. Effect of temperature on the evolution of free amino acid and biogenic amine contents during storage of Azeitão cheese. Food Chem. 75: 287-291.

Polska Norma PN-EN-ISO 6867. 2002. Pasze Oznaczanie Zawartości Witaminy E. Metoda Wysokosprawnej Chromatografii Cieczowej - Tokoferole w Paszach.

Polska Norma PN-EN ISO 6497. 2002. Pasze Pobieranie Próbek.

Reklewska, B., A. Oprządek, Z. Reklewski, L. Panicke, B. Kuczyńska and J. Oprządek. 2002. Alternative for modifying the fatty acid composition and decreasing the cholesterol level in the milk of cows. Livest. Prod. Sci. 76: 235-243.

Rhee, K. S., T. R. Dutson, G. C. Smith, R. L. Hostetler and R. Reiser. 1982. Cholesterol content of raw and cooked beef longissimus muscles with different degrees of marbling. J. Food Sci. 47: 716-719.

Roig-Sagues, A. X., A. P. Molina and M. Hernández-Herrero. 2002. Histamine and tyramine-forming microorganisms in Spanish traditional cheeses. Eur. Food Res. Technol. 215: 96-100.

Shalaby, A. 1996. Significance of biogenic amines to food safety and human health. Food Res. Int. 29: 675-690.

Shingfield, K. J., P. Salo-Väänänen, E. Pahkala, V. Toivonen, S. Jaakkola, V. Piironen and P. Huhtanen. 2005. Effect of forage conservation method concentrate level and propylene glycol on the fatty acid composition and vitamin content of cows' milk. J. Dairy Res. 72: 349-361.

Slačanac, V., R. Božanić, J. Hardi, J. Rezessynészabó, M. Lučan and V. Krstanović. 2012. Nutritional and therapeutic value of fermented caprine milk. Int. J. Dairy Technol. 63: 171-189.

Spizzirri, U. G., D. Restuccia, M. Curcio, O. Parisi, I. F. lemma and N. Picci. 2013. Determination of biogenic amines in different cheese samples by LC with evaporative light scattering detector. J. Food Compos. Anal. 29: 43-51.

Strzałkowska, N., A. Jóźwik, E. Bagnicka, E. Poławska, J. Krzyżewski, B. Pyzel and J. O. Horbańczuk. 2012. Fatty acid profiles cholesterol concentration and susceptibility to lipolitic fat fraction in goat's milk. Med. Wet. 68: 40-44.

Talpur, F. N., M. I. Bhanger, A. A. Khooharo and G. Z. Memon. 2008. Seasonal variation in fatty acid composition of milk from ruminants reared under the traditional feeding system of Sindh Pakistan. Livest. Sci. 118: 166-172.

Ulbricht, T. L. V. and D. A. T. Southgate. 1991. Coronary heart disease; seven dietary factors. Lancet. 338: 985-992.

Wiśniewska, K. and A. Reps. 2007. Aminy biogenne w serach dojrzewających. Przegląd Mleczarski. 10: 4-5.

Wolanciuk, A., J. Barłowska, R. Pastuszka and B. Topyła. 2013. Podstawowy skład chemiczny i wybrane parametry tłuszczu mleka koziego z okresu żywienia letniego i jesienno-zimowego. Roczniki Nauk. PTZ. 9: 63-70.

Wood, J. D., R. I. Richardson, G. R. Nute, A. V. Fisher, M. M. Campo, E. Kasapidou, P. R. Sheard and M. Enser. 2003. Effect of fatty acid on meat quality; A review. Meat Sci. 6: 21-32. 